\title{
Anti-inflammatory effects of Lycium barbarum leaf extracts in lipopolysaccharide-induced RAW 264.7 macrophage cells and isolation of secondary metabolites
}

\author{
Beril KADIOĞLU YAMAN 1 * (D), Ozan ŞEN 2 (D), Aycan SALMAN 2 (D), Hande SİPAHİ ${ }^{2}$ (D), \\ Norbert KUSZ 4 (D), Judit HOHMANN 4 (D), Hasan KIRMIZIBEKMEZ 5 (D) \\ 1 Department of Pharmacology, Faculty of Pharmacy, Yeditepe University, TR-34755 Kayışdağı, İstanbul, Turkey \\ 2 Faculty of Pharmacy, Yeditepe University, TR-34755 Kayışdağı, İstanbul, Turkey \\ 3 Department of Toxicology, Faculty of Pharmacy, Yeditepe University, TR-34755 Kayışdağı, İstanbul, Turkey \\ 4 Department of Pharmacognosy, Interdisciplinary Excellence Centre, University of Szeged, 6720, Szeged, Hungary \\ 5 Department of Pharmacognosy, Faculty of Pharmacy, Yeditepe University, TR-34755 Kayışdağı, İstanbul, Turkey \\ * Corresponding Author. E-mail beril.kadioglu@yeditepe.edu.tr (B.KY.); Tel. +90-216-578 0558.
}

Received: 22 February 2019 / Revised: 08 April 2019 / Accepted: 22 May 2019

ABSTRACT: Lycium barbarum possesses many bioactivities such as antidiabetic, antioxidant, antitumor, and immunomodulatory activities. In the present study, the $\mathrm{MeOH}$ extract $(1 \mathrm{mg} / \mathrm{mL})$ prepared from the leaves of $L$. barbarum cultivated in Turkey exerted significant anti-inflammatory activity via reducing the release of nitric oxide (NO) in LPSstimulated RAW 264.7 macrophages comparable to positive control indomethacin. Then, the extract was partitioned against $\mathrm{CH}_{2} \mathrm{Cl}_{2}$ and EtOAc to yield $\mathrm{CH}_{2} \mathrm{Cl}_{2}$, EtOAc and $\mathrm{H}_{2} \mathrm{O}$ subextracts which were also submitted to the same tests. Among the tested extracts, EtOAc $(0.25$ and $0.5 \mathrm{mg} / \mathrm{mL})$, and $\mathrm{CH}_{2} \mathrm{Cl}_{2}(0.25 \mathrm{mg} / \mathrm{mL})$ subextracts showed significant $\mathrm{NO}$ production inhibitory activities. The tested extracts also inhibited the production of $\mathrm{PGE}_{2}$ slightly. Successive chromatographic studies on the EtOAc subextract led to the isolation of three secondary metabolites, including chlorogenic acid, hesperidin and rutin as the potential bioactive compounds that are responsible for the in vitro antiinflammatory activity of the EtOAc subextract. The structures were elucidated based on 1D and 2D NMR spectra. Although chlorogenic acid and rutin were previously reported from leaves of L. barbarum, this is the first report of hesperidin from L. barbarum to the best of our knowledge.

KEYWORDS: Lycium barbarum; anti-inflammatory activity, NO inhibition, flavonoid glycosides, hesperidin.

\section{INTRODUCTION}

Lycium barbarum L. (Goji berry) belonging to Solanaceae family is a tree native to Asian countries mainly to China. Today, it is cultivated and naturalized in European and Mediterranean countries. There are eight Lycium species naturally growing in the Flora of Turkey [1]. The fruits of L. barbarum also known as 'gou ji' is a well-known functional food and it is commonly used as a medicinal plant in Traditional Chinese Medicine (TCM). Fruits (Fructus Lycii) and root barks (Cortex Lycii) are recorded in Pharmacopoeia of the People's Republic of China. In TCM, fruits are used for liver and kidney problems and to improve eyesight; root barks are used for anti-inflammatory, anti-diabetic, antipyretic effects, also used for the night-sweats and cough; leaves are used for tonifying deficiency, nourishing the kidney, clearing heat and brightening the eyes [2]. Hypoglycemic, antioxidant, antitumor, and immuno-modulatory effects of fruits of L. barbarum were shown in several in vivo and in vitro studies [3]. Furthermore, there are some clinical studies that show the antidiabetic [4], immuno-modulatory [5] and antioxidant [6] effects of fruits. Although there are many studies performed on the fruits, the number of the researches focusing on the bioactivities of the leaves are confined to a few studies which report the antioxidant [7], antimicrobial [7] and immuno-modulatory [8] effects. In previous phytochemical studies, several polysaccharides, flavonoids, aromatic acids and terpenoids were reported from L. barbarum leaves $[2,9-11]$.

\footnotetext{
How to cite this article: Kadığlu Yaman B, Şen O, Salman A, Sipahi H, Kusz N, Hohmann J, Kırmızıbekmez H. Anti-inflammatory effects of Lycium barbarum leaf extracts in lipopolysaccharide-induced RAW 264.7 macrophage cells and isolation of secondary metabolites. J Res Pharm. 2019; 23(4): 740-748.
} 
Growing scientific evidence suggests that, chronic inflammation may lead to serious diseases and therefore natural products have attracted more attention due to their anti-inflammatory properties [12]. Macrophages are essential for host immunity and by detecting pathogenic substances, they initiate and regulate inflammatory responses [13]. Lipopolysaccharide (LPS), an endotoxin derived from Gram-negative bacteria, is a powerful activator of macrophage cells, and activated macrophages are known to produce inflammatory mediators. Over-production of these inflammatory mediators, prostaglandins and nitric oxide (NO) are generated by activated cyclooxygenase-2 (COX-2) and inducible NO synthase (iNOS) [14]. Therefore, inhibiting the production of $\mathrm{NO}$ and prostaglandin $\mathrm{E}_{2}\left(\mathrm{PGE}_{2}\right)$ is an important therapeutic target in the development of anti-inflammatory agents. The potential medicinal importance of $L$. barbarum prompted us to investigate the potential anti-inflammatory activities of the extracts prepared from the leaves of L. barbarum which is cultivated in Konya province of Turkey, as well as to isolate the main secondary metabolites.

\section{RESULTS}

\subsection{Cell viability}

Cytotoxicity assay was performed for $\mathrm{MeOH}$, EtOAc, $\mathrm{CH}_{2} \mathrm{Cl}_{2}$ and $\mathrm{H}_{2} \mathrm{O}$ extracts at different concentrations $(0.25,0.50$ and $1 \mathrm{mg} / \mathrm{mL})$ and the results were shown in Figure 1 . The viability of RAW 264.7 cells decreased below $70 \%$ after 24 hours exposure to EtOAc $(1 \mathrm{mg} / \mathrm{mL})$ and $\mathrm{CH}_{2} \mathrm{Cl}_{2}(0.5$ and $1 \mathrm{mg} / \mathrm{mL})$ extracts. Other concentrations of the extracts, that resulted a cell viability $>70 \%$, was used for the nitrite assay. Therefore, the possibility that the observed NO production inhibitory activities were due to the cytotoxicity was excluded.

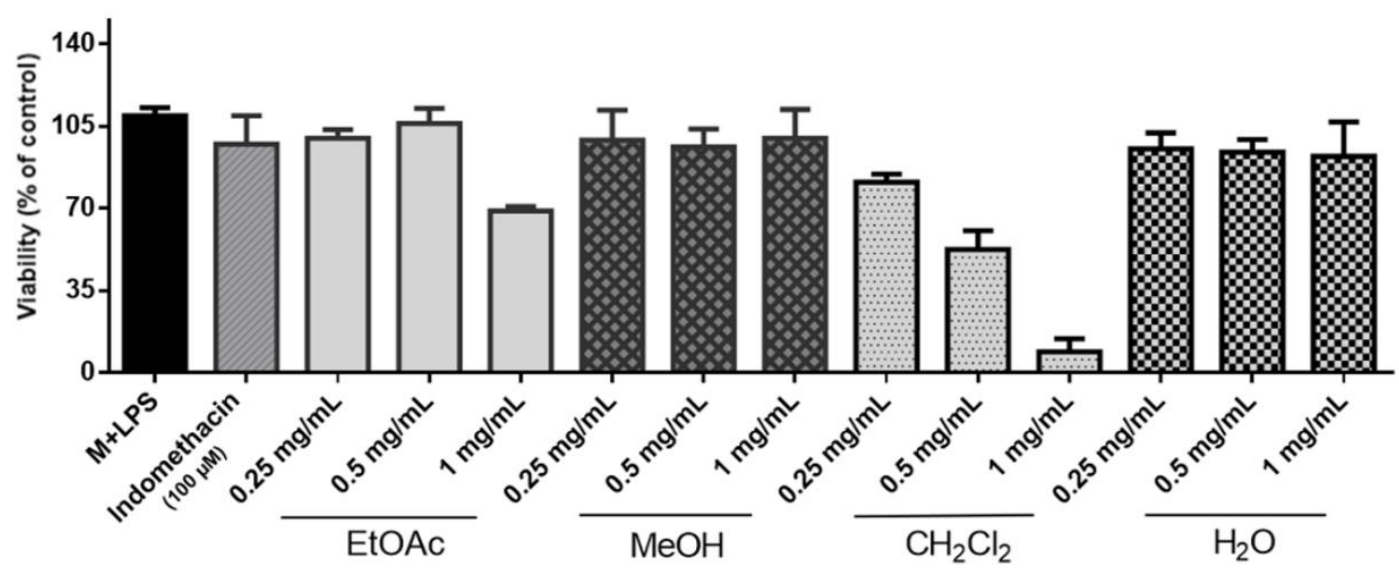

Figure 1. Effects of L. barbarum leaf extracts (EtOAc, $\mathrm{MeOH}, \mathrm{CH}_{2} \mathrm{Cl}_{2}$ and $\mathrm{H}_{2} \mathrm{O}$ ) on the viability of LPStreated RAW 264.7 macrophages at different concentrations $(\mathrm{mg} / \mathrm{mL})$.

\subsection{Nitrite assay}

The extracts were tested for their inhibitory activities against LPS-induced nitrite production in RAW 264.7 cells, the nitrite concentrations were shown in Table 1. Among the tested extracts, the crude $\mathrm{MeOH}(1$ $\mathrm{mg} / \mathrm{mL})$ extract and the EtOAc $(0.25$ and $0.5 \mathrm{mg} / \mathrm{mL})$, and $\mathrm{CH}_{2} \mathrm{Cl}_{2}(0.25 \mathrm{mg} / \mathrm{mL})$ subextracts showed significant nitrite production inhibitory activities while $\mathrm{H}_{2} \mathrm{O}$ subextract was inactive. The EtOAc subextract which displayed nitrite inhibition $59.32 \%$ and $84.96 \%$ at 0.25 and $0.5 \mathrm{mg} / \mathrm{mL}$ concentrations respectively and caused less cytotoxicity to RAW 264.7 cells were submitted to chromatographic separations.

\subsection{Prostaglandin $E_{2}$ assay}

The crude $\mathrm{MeOH}$ extract and the EtOAc and $\mathrm{CH}_{2} \mathrm{Cl}_{2}$ subextracts were analyzed for their inhibitory activities against Prostaglandin E2 production in RAW 264.7 cells and the results are presented in Table 1. The crude $\mathrm{MeOH}$ extract and the EtOAc and $\mathrm{CH}_{2} \mathrm{Cl}_{2}$ subextracts were selected for further $\mathrm{PGE}_{2}$ Assay as they showed significant nitrite inhibition. 
Table 1. Results of nitrite and PGE 2 assays in LPS-induced RAW 264.7 macrophages. Values are expressed as the mean \pm SD of various experiments. ${ }^{*} p<0.05,{ }^{* *} p<0.01$, and ${ }^{* * *} p<0.001$ indicate a significant difference from the LPS-stimulated control group.

\begin{tabular}{llccc}
\hline & & Nitrite $(\boldsymbol{\mu M})$ & $\begin{array}{c}\text { Nitrite } \\
\text { inhibition } \%\end{array}$ & PGE $_{2}(\mathbf{p g} / \mathbf{m L})$ \\
\hline LPS Control & & $26 \pm 0.05$ & - & $3343.25 \pm 52.43$ \\
\hline MeOH Extract & $0.5 \mathrm{mg} / \mathrm{mL}$ & $15.96 \pm 1.63 * *$ & $38.62 \pm 6.15$ & $3380.33 \pm 0.05$ \\
\hline $\begin{array}{l}\text { EtOAc } \\
\text { subextract }\end{array}$ & $1 \mathrm{mg} / \mathrm{mL}$ & $4.33 \pm 0.68 * * *$ & $83.36 \pm 2.65$ & $3009.16 \pm 70.79 *$ \\
\hline & $0.25 \mathrm{mg} / \mathrm{mL}$ & $10.58 \pm 4.08^{* *}$ & $55.48 \pm 10.16$ & $3096.38 \pm 194.13$ \\
\hline $\begin{array}{l}\mathbf{C H}_{2} \mathbf{C l}_{2} \\
\text { subextract }\end{array}$ & $0.5 \mathrm{mg} / \mathrm{mL}$ & $3.91 \pm 0.64 * * *$ & $84.96 \pm 2.47$ & $3145.27 \pm 24.67$ \\
\hline $\begin{array}{l}\mathbf{r H} \\
\text { In subextract }\end{array}$ & $0.25 \mathrm{mg} / \mathrm{mL}$ & $5.77 \pm 1.63 * * *$ & $77.82 \pm 6.23$ & $2927.19 \pm 91.81 *$ \\
\hline Indomethacin & $100 \mu \mathrm{mL}$ & $25.02 \pm 0.54$ & $0.16 \pm 1.18$ & \\
\hline
\end{tabular}

\subsection{Structure elucidation of the isolates}

Three compounds were isolated from the EtOAc subextract. These compounds were identified as chlorogenic acid [15], hesperidin [16] and rutin [17] by comparison of their spectroscopic data with those reported in the literature. ${ }^{1} \mathrm{H}$ NMR spectra of chlorogenic acid, rutin and hesperidin are presented in figures 2-4. JMOD-13C NMR and HMBC spectra of hesperidin are given in figures 5-6 respectively.

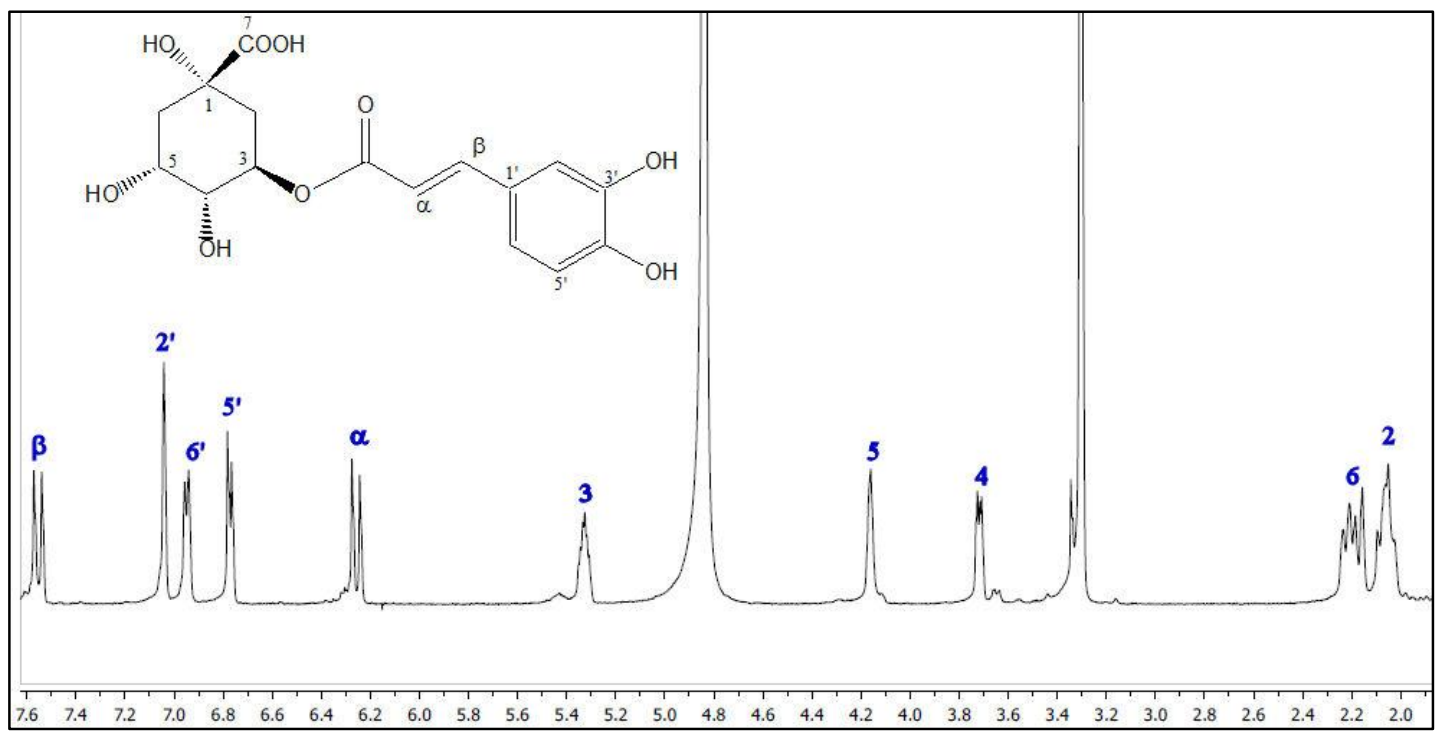

Figure 2. ${ }^{1} \mathrm{H}$ NMR spectrum of chlorogenic acid in $\mathrm{CD}_{3} \mathrm{OD}$. 


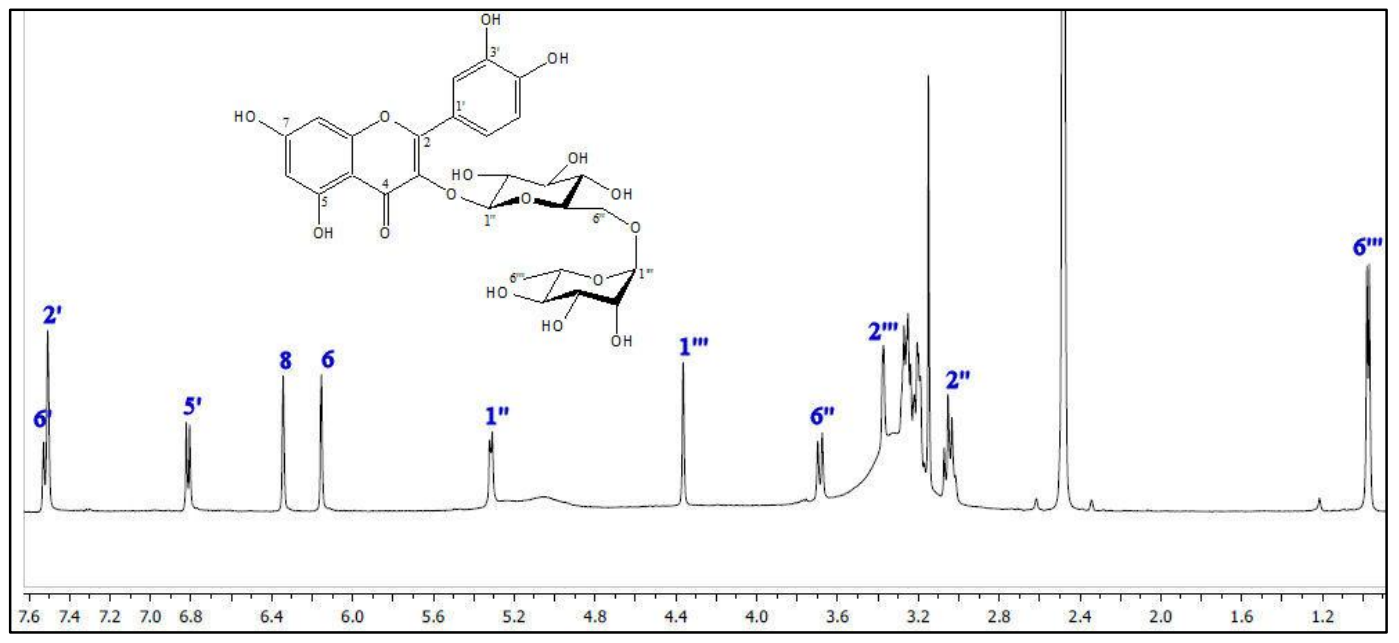

Figure 3. ${ }^{1} \mathrm{H}$ NMR spectrum of rutin in DMSO- $d_{6}$.

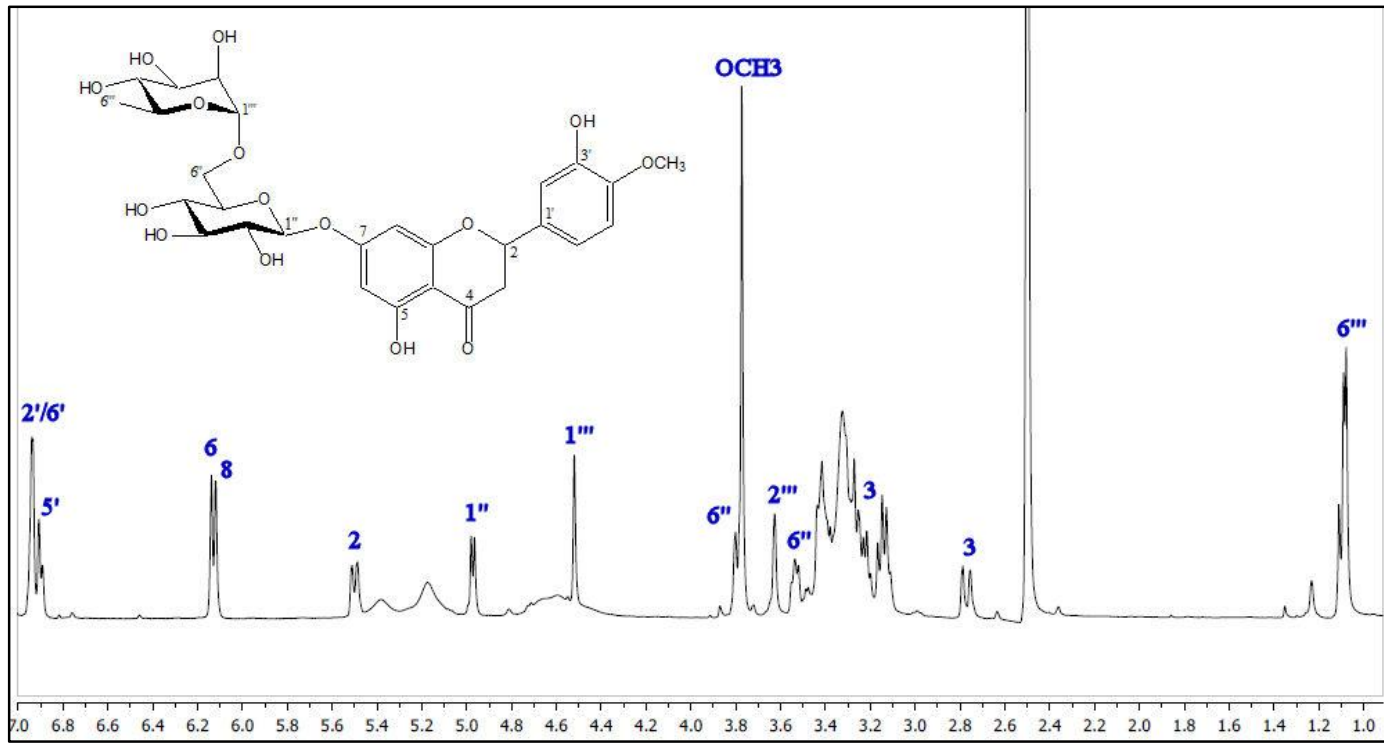

Figure 4. ${ }^{1} \mathrm{H}$ NMR spectrum of hesperidin in DMSO- $d_{6}$.

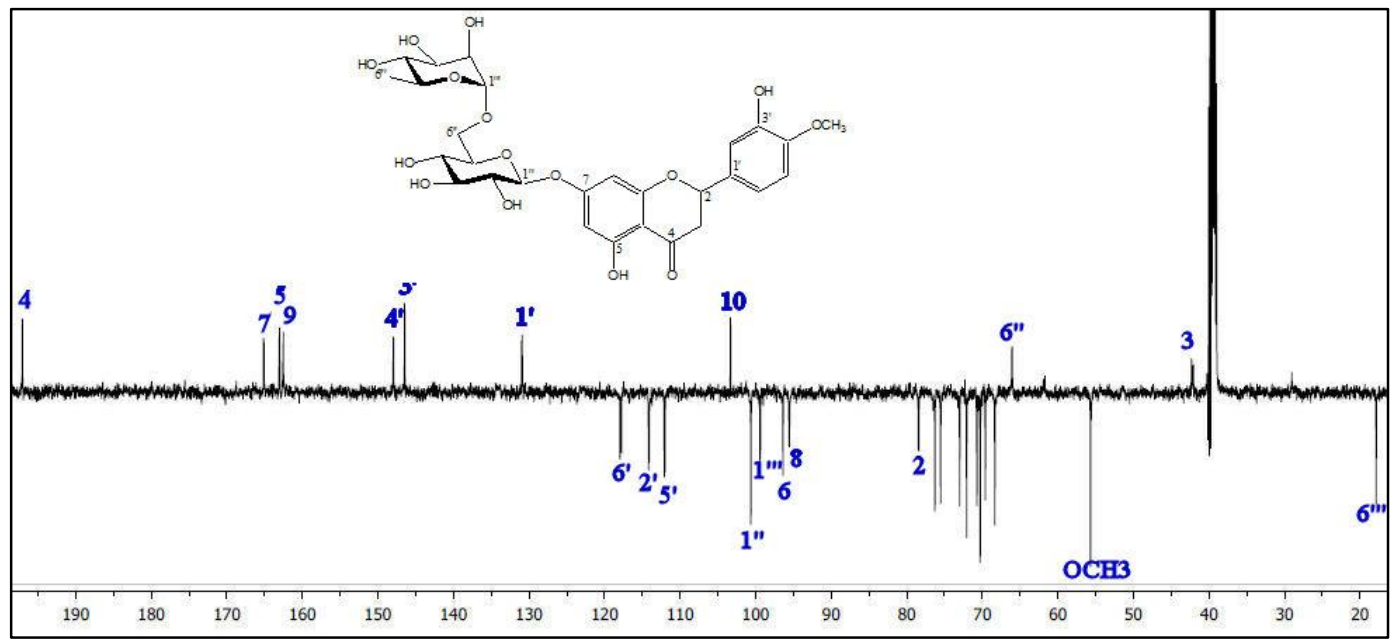

Figure 5. JMOD ${ }^{13} \mathrm{C}$ NMR spectrum of hesperidin in DMSO- $d_{6}$. 


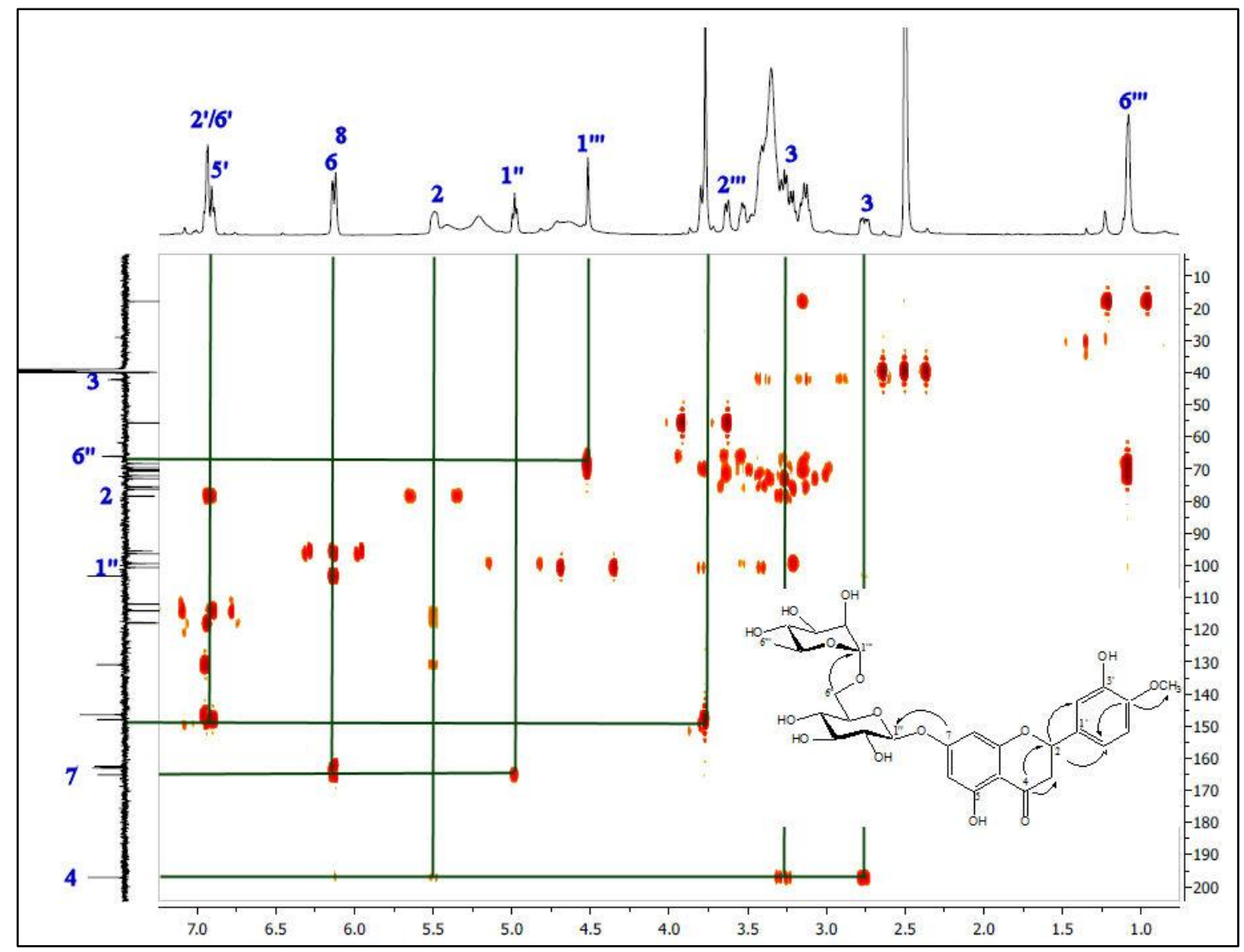

Figure 6. HMBC spectrum of hesperidin.

\section{DISCUSSION}

Inflammation is a physiological response of the organism to injuries such as trauma, infection or an immune response to harmful stimuli. This biologic response is a defense mechanism of the organisms [18]. Acute inflammation occurs with several typical processes including increased blood flow, increased permeability, and migration of neutrophils and eosinophils. These migrated immune cells can neutralize and eliminate potentially injurious stimuli [19]. Growing evidence has shown that there is a relationship between chronic inflammation and several diseases. Inflammation plays an important role in the development of insulin resistance and type 2 diabetes, obesity, metabolic syndrome, in the etiology of atherosclerosis, contributes to the pathology of Parkinson's disease, and also involved in the etiology of Alzheimer's disease $[20,21]$. Nitric oxide is a key inflammatory mediator, and over production of NO occurs in both acute and chronic inflammation. $\mathrm{NO}$ is synthesized from L-arginine by NO synthases (NOS) enzymes. Lipopolysaccharide is one of the most powerful activators of macrophage cells and inducible iNOS is mainly expressed in the activated macrophages. During inflammation, $\mathrm{PGE}_{2}$, another well-studied inflammatory mediator, is produced from arachidonic acid. Prostaglandins are generated from arachidonic acid by cyclooxygenase 1 (COX-1) and cyclooxygenase 2 (COX-2) enzymes. COX-2 is the inducible form and responsible from the synthesis of pro-inflammatory prostaglandins. LPS induces COX-2 expression and high levels of $\mathrm{PGE}_{2}$ released in the sites of inflammation [22].

Many of the medicinal plants and their isolates were investigated for their potential anti-inflammatory activities. The fruits of L. barbarum is a famous nutraceutical due to its highly nutritive properties and also several in vivo and in vitro studies revealed the hypoglycemic, antioxidant, antitumor, and immunomodulatory effects of the fruits [3]. Recently, other organs of this tree such as leaves have received the attention of the researchers. Wang et al., determined the hydroxycinnamic acid amides (HCAA) from the leaves and root barks of L. barbarum and screened the anti-inflammatory activities of the HCAA compounds [23]. However, the in vitro anti-inflammatory activities of leaf extracts of this species have never been studied to the best of our knowledge. In this study, we investigated the anti-inflammatory effects of the extracts of $L$. barbarum leaves collected from Turkey. In order to screen the anti-inflammatory activities of the L. barbarum 
extracts, cell viability assays were performed to determine proper testing concentrations and to evaluate their potential cytotoxicities.

The crude $\mathrm{MeOH}$ extract $(1 \mathrm{mg} / \mathrm{mL})$ as well as the EtOAc $(0.25$ and $0.5 \mathrm{mg} / \mathrm{mL})$ and $\mathrm{CH}_{2} \mathrm{Cl}_{2}(0.25$ $\mathrm{mg} / \mathrm{mL}$ ) subextracts displayed significant NO production activity on LPS-stimulated RAW 264.7 cells.

Furthermore, $\mathrm{MeOH}(1 \mathrm{mg} / \mathrm{mL})$ and $\mathrm{CH}_{2} \mathrm{Cl}_{2}(0.25 \mathrm{mg} / \mathrm{mL})$ extracts exhibited low to mild inhibitory activity on PGE 2 production in LPS-stimulated RAW 264.7 cells.

EtOAc subextract of L. barbarum leaves were selected for the isolation of main secondary metabolites due to its highest $\mathrm{NO}$ production inhibitory activity at $0.50 \mathrm{mg} / \mathrm{mL} . \mathrm{CH}_{2} \mathrm{Cl}_{2}$ extract also showed significant anti-inflammatory activity at $0.25 \mathrm{mg} / \mathrm{mL}$, however cell viability decreased below $70 \%$ after 24 hours exposure at higher concentrations $\left(0.50\right.$ and $1 \mathrm{mg} / \mathrm{mL}$ ). Moreover, $\mathrm{CH}_{2} \mathrm{Cl}_{2}$ extract was found to be moderately or strongly cytotoxic since $1 \mathrm{mg} / \mathrm{mL}$ extract led to more than $30 \%$ cell death. Three compounds were isolated from EtOAc subextract. The isolates were characterized as chlorogenic acid [15], hesperidin [16] and rutin [17] respectively by comparison of their NMR data with those reported in the literatures. Chlorogenic acid and rutin were previously reported from the leaves of L. barbarum [7]. However, hesperidin was isolated and identified for the first time from L. barbarum in this study.

Lopatriello et al, identified the major bioactive compounds present in fruits and leaves of L. barbarum [24]. Rutin and chlorogenic acid was characterized as a major component in L. barbarum green leaves. For both leaves and flower extracts, the dominant molecule among the phenolic acids was chlorogenic acid, and rutin was represented as the major flavonoid [25,26]. Natural rutin $\left(3^{\prime}, 4,5,7\right.$-tetrahydroxyflavone-3-rutinoside), is an attractive phytochemical molecule with various pharmacological activities. Kazlowska et al, investigated the anti-inflammatory effects of phenolic compounds isolated from plant extract and rutin reduced the production of NO in RAW 264.7 macrophages [27]. Guardia et al, studied the anti-inflammatory activity of rutin, using a rat model of inflammation [28]. Results clearly showed that, rutin inhibited both acute and chronic phases of the experimental model of inflammation. Liu et al, investigated the in vitro anti- inflammatory and cartilage- protective role of chlorogenic acid and the results indicated that the inhibition of COX-2, $\mathrm{PGE}_{2}$, iNOS, NO is the underlying mechanism of its anti- inflammatory activity [29].

According to our results, hesperidin was an important component of the L. barbarum leaf extract, which has been identified by this study for the first time. Different studies have demonstrated the anti-inflammatory effects of hesperidin and it is considered that hesperidin down-regulates the over-activated macrophages and up-regulates the function of dysfunctional T lymphocytes [30]. Accordingly, chlorogenic acid, rutin and hesperidin seems to be the responsible compounds for the in vitro anti-inflammatory effects of L. barbarum leaves. Our findings along with the previous studies are in favor of the traditional uses of the L. barbarum against inflammatory mediated diseases.

\section{CONCLUSION}

In conclusion, the leaves of L. barbarum exerted significant inhibitory effects on the production of NO and $\mathrm{PGE}_{2}$ in LPS-stimulated RAW 264.7 cells implying its anti-inflammatory activity. Chlorogenic acid, rutin and hesperidin were isolated from the EtOAc subextract as the potential anti-inflammatory compounds. Based on these results further in vitro and in vivo studies could be necessary to fully establish the anti-inflammatory activities of the leaf extract.

\section{MATERIALS AND METHODS}

\subsection{General}

Silica gel 60 F254 precoated TLC plates were used for monitoring fractions during chromatographic separations. Sephadex LH-20 (Fluka) was used for gel filtration chromatography. For medium-pressure liquid chromatographic (MPLC) separations, the Sepacore ${ }^{\circledR}$ Flash Systems X10/X50 (Büchi) system was used with Redi sep columns (LiChroprep $\mathrm{C}_{18}: 30 \mathrm{~g}$ and 15,5 g; Teledyne Isco). NMR spectra were recorded in $\mathrm{CD}_{3} \mathrm{OD}$ and DMSO-d6 on a Bruker Avance DRX 500 spectrometer at $500 \mathrm{MHz}$ for ${ }^{1} \mathrm{H}$ and $125 \mathrm{MHz}$ for ${ }^{13} \mathrm{C}$.

\subsection{Plant Material}

The leaves of L. barbarum L. were collected in June 2016 from Temmuz Organik Çiftliği, Konya, Turkey where the plant species is cultivated. The plant material was identified by Prof. Dr. Hasan Kırmızibekmez and Ozan Şen. A voucher specimen (YEF 16012) has been deposited at the Herbarium of the Department of Pharmacognosy, Faculty of Pharmacy, Yeditepe University, İstanbul, Turkey. 


\subsection{Extraction and isolation}

The shade-dried leaves $(300 \mathrm{~g})$ were macerated with $\mathrm{MeOH}(1.25 \mathrm{~L})$ at room temperature for 3 days and then extracted at $45{ }^{\circ} \mathrm{C}$ for $4 \mathrm{~h}$. The same process repeated, and the extracts were combined $(67 \mathrm{~g})$. The concentrated $\mathrm{MeOH}$ extracts were suspended in $\mathrm{H}_{2} \mathrm{O}$ and then partitioned with $\mathrm{CH}_{2} \mathrm{Cl}_{2}$ and EtOAc, respectively. The organic solvents were evaporated to dryness to give $\mathrm{CH}_{2} \mathrm{Cl}_{2}(16.1 \mathrm{~g})$, EtOAc $(1.8 \mathrm{~g})$ subextracts, while $\mathrm{H}_{2} \mathrm{O}$ phase were lyophilized to yield remaining water extract $\left(\mathrm{rH}_{2} \mathrm{O}, 44.5 \mathrm{~g}\right)$. The EtOAc subextract (1.8 g) was subjected to $100 \mathrm{~g}$ Sephadex column chromatography eluted with $\mathrm{MeOH}$ to give six fractions, A-F. Fraction E (157 mg) was further separated by $\mathrm{C}_{18}-\mathrm{MPLC}(30 \mathrm{~g})$ eluted with $\mathrm{MeOH}-\mathrm{H}_{2} \mathrm{O}$ mixture $(0 \rightarrow 70 \% \mathrm{MeOH})$ to give three fractions, $\mathrm{E}_{1}-\mathrm{E}_{3}$. Fraction $\mathrm{E}_{2}(17 \mathrm{mg})$ was separated by Sephadex LH-20 (6 g) column chromatography eluted with $\mathrm{MeOH}$ to give rutin $(6 \mathrm{mg}$ ). Furthermore, fraction $\mathrm{F}(55 \mathrm{mg})$ was separated by $\mathrm{C}_{18}-\mathrm{MPLC}(15.5 \mathrm{~g})$ eluted with $\mathrm{MeOH}-\mathrm{H}_{2} \mathrm{O}$ mixture $(0-100 \% \mathrm{MeOH})$ to give chlorogenic acid (5 $\mathrm{mg}$ ) and hesperidin (2 mg).

\subsection{Cell culture}

RAW 264.7 macrophage cells were obtained from American Type Culture Collection (ATCC). Cells were cultured in DMEM (Gibco, UK), supplemented with 10\% FBS (Gibco, USA) and 1\% streptomycin and penicillin (Gibco, USA) at $37^{\circ} \mathrm{C}$ in $5 \% \mathrm{CO}_{2}$.

\subsection{Cell cytotoxicity}

RAW 264.7 cells at the density of $1 \times 10^{5}$ cells per well with $250 \mu \mathrm{L}$ of culture medium were treated with plant extractions for 24 hours in the presence of LPS $(1 \mu \mathrm{g} / \mathrm{mL})$. The medium was then removed, $100 \mu \mathrm{L}$ of 0.5 $\mathrm{mg} / \mathrm{mL}$ MTT (AppliChem, Germany) solution was added and incubated for $2 \mathrm{~h}$. MTT (3-(4,5-dimethylthiazol2-yl)-2,5-diphenyltetrazolium bromide), a tetrazolium salt, is yellow colored and at the end the incubation period, water-insoluble dark blue crystals are formed in the mitochondria of living cells. The medium was removed and $100 \mu \mathrm{L}$ of isopropanol (Sigma-Aldrich, Germany) were added in each well, and optical absorbance was measured at $570 \mathrm{~nm}$ [23]. The relative cell viability (\%) was calculated according to following equation, where OD represents the optic density. Cell viability $(\%)=$ OD570 (sample) / OD570 (medium control) $\times 100$

\subsection{Nitrite assay}

RAW 264.7 cells were seeded into a 48 -well culture plate at the density of $1 \times 10^{5}$ cells per well with 250 $\mu \mathrm{L}$ of culture medium and incubated for $24 \mathrm{~h}$. The cells were pretreated with plant extracts (EtOAc, $\mathrm{MeOH}$, $\left.\mathrm{CH}_{2} \mathrm{Cl}_{2}\right)$ and the reference molecule, indomethacin $(100 \mu \mathrm{M}) .2$ hours later, cells were stimulated with $1 \mu \mathrm{g} / \mathrm{mL}$ LPS and after $22 \mathrm{~h}$, the nitrite concentration in the medium was measured by using a colorimetric method based on the Griess reaction. $50 \mu \mathrm{L}$ Griess reagent [1\% sulfanilamide (Sigma-Aldrich, USA) and 0.1\% N-(1naphthyl) ethylendiamine dihydrochloride (Sigma-Aldrich, USA) in 5\% phosphoric acid (Mettler, Switzerland)] was added to $50 \mu \mathrm{L}$ of medium and incubated in dark for $10 \mathrm{~min}$ at room temperature. The absorbance was measured at $540 \mathrm{~nm}$, using a microplate reader (Microplate photometer, Multiskan Ascent, Finland) [27]. A sodium nitrite (Fluka Chemika, Germany) standard curve was used to calculate the amount of nitrite in culture medium and \% inhibition was calculated by using the following equation:

$\%$ Inhibition $=100-\left[\left(\mathrm{N}_{1} \times 100\right) / \mathrm{N}_{0}\right]$

$\mathrm{N}_{0}$ : Nitrite amount $(\mu \mathrm{M})$ of LPS-treated medium control,

$\mathrm{N}_{1}$ : Nitrite amount $(\mu \mathrm{M})$ of tested samples

\subsection{Prostaglandin $E_{2}$ assay}

RAW 264.7 cells were seeded at a density of $1 \times 10^{5}$ cells in 48 -well culture plates. The culture conditions used were the same as those described above for the nitrite assay. Prostaglandin $E_{2}$ levels in cell supernatant was measured by using a PGE 2 ELISA kit, according to the manufacturer's instructions (Abcam, UK).

\subsection{Statistics}

All results were expressed as the mean \pm SD of experiments. Statistical significance was determined by one-way ANOVA followed by Tukey's test using a computerized statistical program \{Graphpad Prism 6.0 (Graphpad Software, San Diego, CA, USA)\}. The data were considered statistically significant if $\mathrm{p}<0.05$. 
Acknowledgements: The authors are grateful to Prof. Dr. Dilek Telci (Yeditepe University, Faculty of Engineering, Department of Genetics and Bioengineering, İstanbul, Turkey) for providing the RAW 264.7 macrophage cells. Financial support from the Economic Development and Innovation Operative Programme GINOP-2.3.2-15-2016-00012 is gratefully acknowledged. Ministry of Human Capacities, Hungary grant 20391-3/2018/FEKUSTRAT is acknowledged.

Author contributions: Concept - B.K.Y., H.S., H.K.; Design - B.K.Y., H.K.; Supervision - H.S., H.K.; Materials - O.Ş., A.S.; Data Collection and/or Processing - B.K.Y., N.K, J.H.; Analysis and/or Interpretation - B.K.Y., H.S., N.K., J.H., H.K.; Literature Search - B.K.Y., O.Ş., A.S.; Writing - B.K.Y., H.K.; Critical Reviews - B.K.Y., O.Ş., A.S., H.S., N.K., J.H., H.K.

Conflict of interest statement: The authors declared no conflict of interest.

\section{REFERENCES}

[1] Davis PH, Flora of Turkey and the East Aegean Islands, sixth ed., Edinburgh University Press, Edinburgh, United Kingdom 1979.

[2] Yao X, Peng Y, Xua LJ, Li L, Wu QL, Xiao PG. Phytochemical and biological studies of Lycium medicinal plants. Chem Biodivers. 2011; 8: 976-1010. [CrossRef]

[3] Amagase H and Farnsworth NR. A review of botanical characteristics, phytochemistry, clinical relevance in efficacy and safety of Lycium barbarum fruit (Goji). Food Res Int. 2011; 44(7): 1702-1717. [CrossRef]

[4] Cai H, Liu F, Zuo P, Huang G, Song Z, Wang T, Lu H, Guo F, Han C, Sun G. Practical application of antidiabetic efficacy of Lycium barbarum polysaccharide in patients with type 2 diabetes. Med Chem. 2015; 11: 383-390. [CrossRef]

[5] Amagase H, Sun B, Nance DM. Immunomodulatory effects of a standardized Lycium barbarum fruit juice in Chinese older healthy human subjects. J Med Food. 2009; 12(5): 1159-1165. [CrossRef]

[6] Amagase H, Sun B, Borek C. Lycium barbarum (goji) juice improves in vivo antioxidant biomarkers in serum of healthy adults. Nutr Res. 2009; 29(1): 19-25. [CrossRef]

[7] Mocan A, Vlase L, Vodnar DC, Bischin C, Hanganu D, Gheldiu AM, Oprean R, Silaghi-Dumitrescu R, Crișan G. Polyphenolic content, antioxidant and antimicrobial activities of Lycium barbarum L. and Lycium chinense Mill. leaves. Molecules. 2014; 19(7): 10056-10073. [CrossRef]

[8] Liu H, Fan Y, Wang W, Liu N, Zhang H, Zhu Z, Liu A. Polysaccharides from Lycium barbarum leaves: isolation, characterization and splenocyte proliferation activity. Int J Biol Macromol. 2012; 51(4): 417-22. [CrossRef]

[9] Dong JZ, Lu DY, Wang Y. Analysis of flavonoids from leaves of cultivated Lycium barbarum L. Plant Foods Hum Nutr. 2009; 64(3): 199-204. [CrossRef]

[10] Dong JZ, Gao WS, Lu DY, Wang Y. Simultaneous extraction and analysis of four polyphenols from leaves of Lycium barbarum L. J Food Biochem. 2011; 35(3): 914-931. [CrossRef]

[11] Wang, Y., Wang Y, Zhao B, Ma HR, Aisa HA. Two new sesquiterpenoid glycosides from the leaves of Lycium barbarum. J Asian Nat Prod Res. 2016; 18(9): 871-7. [CrossRef]

[12] Kumar KP, Nicholls AJ, Wong CHY. Partners in crime: neutrophils and monocytes/macrophages in inflammation and disease. Cell Tissue Res. 2018; 371: 551-565. [CrossRef]

[13] Phan AT, Goldrath AW, Glass CK. Metabolic and epigenetic coordination of T cell and Macrophage immunity. Immunity. 2017; 46(5): 714-729. [CrossRef]

[14] Tsai HH, Lee WR, Wang PH, Cheng KT, Chen YC, Shen SC. Propionibacterium acnes-induced iNOS and COX-2 protein expression via ROS-dependent NF-kB and AP-1 activation in macrophages. J Dermatol Sci. 2013; 69(2): $122-131$. [CrossRef]

[15] López-Martínez LM, Santacruz-Ortega H, Navarro RE, Sotelo-Mundo RR, González-Aguilar GA. A ${ }^{1} \mathrm{H}$ NMR investigation of the interaction between phenolic acids found in mango (Manguifera indica cv Ataulfo) and papaya (Carica papaya cv Maradol) and 1,1-diphenyl-2-picrylhydrazyl (DPPH) Free Radicals. PLoS ONE. 2015; 10(11): 1-11. [CrossRef]

[16] Lahmer N, Belboukhari N, Cheriti A, Sekkoum K. Hesperidin and hesperitin preparation and purification from Citrus sinensis peels. Der Pharma Chemica. 2015; 7(2): 1-4.

[17] Fathiazad F, Delazar A, Amiri R, Sarker SD. Extraction of flavonoids and quantification of rutin from waste tobacco leaves. 2006; 5(3): 222-227.

[18] Medzhitov R. Inflammation 2010: New Adventures of an Old Flame. Cell. 2010; 140: 771-776. [CrossRef] 
[19] Nathan C and Ding A. Nonresolving inflammation. Cell. 2010; 140: 871-882. [CrossRef]

[20] Handschin C and. Spiegelman BM. The role of exercise and PGC1a in inflammation and chronic disease. Nature. 2008; 454(7203): 463-469. [CrossRef]

[21] Minihane AM, Vinoy S, Russell WR, Baka A, Roche HM, Tuohy KM, Teeling JL, Blaak EE, Fenech M, Vauzour D, McArdle HJ, Kremer BHA, Sterkman L, Vafeiadou K, Benedetti MM, Williams CM, Calder PC. Low-grade inflammation, diet composition and health: Current research evidence and its translation. Br J Nutr. 2015; 114: 999_ 1012. [CrossRef]

[22] Bogdan C. Nitric oxide synthase in innate and adaptive immunity: An update. Trends Immunol. 2015; 36(3): 161-178. [CrossRef]

[23] Wang S, Suh JH, Hung WL, Zheng X, Wang Y, Ho CT. Use of UHPLC-TripleQ with synthetic standards to profile anti-inflammatory hydroxycinnamic acid amides in root barks and leaves of Lycium barbarum. J Food Drug Anal. 2018; 26: 572-582. [CrossRef]

[24] Lopatriello A, Previtera R, Pace S, Werner M, Rubino L, Werz O, Taglialatela-Scafati O, Forino M. NMR-based identification of the major bioactive molecules from an Italian cultivar of Lycium barbarum. Phytochemistry. 2017; 144: 52-57. [CrossRef]

[25] Mocan A, Vlase L, Vodnar DC, Bischin C, Hanganu D, Gheldiu AM, Oprean R, Silaghi-Dumitrescu R, Crișan G. Polyphenolic content, antioxidant and antimicrobial activities of Lycium barbarum L. and Lycium chinense Mill. leaves. Molecules. 2014; 19: 10056-10073. [CrossRef]

[26] Mocan A, Vlase L, Vodnar DC, Gheldiu AM, Oprean R, Crișan G. Antioxidant, antimicrobial effects and phenolic profile of Lycium barbarum L. flowers. Molecules. 2015; 20: 15060-15071. [CrossRef]

[27] Kazłowska K, Hsu T, Hou CC, Yang WC, Tsai GJ. Anti-inflammatory properties of phenolic compounds and crude extract from Porphyra dentate. J Ethnopharmacol. 2010; 128: 123-130. [CrossRef]

[28] Guardia T, Rotelli AE, Juarez AO, Pelzer LE. Anti-inflammatory properties of plant flavonoids. Effects of rutin, quercetin and hesperidin on adjuvant arthritis in rat. Il Farmaco. 2001; 56: 683-687. [CrossRef]

[29] Liu CC, Zhang Y, Dai BL, Ma YJ, Zhang Q, Wang Y, Yang H. Chlorogenic acid prevents inflammatory responses in IL-1 $\beta$-stimulated human SW-1353 chondrocytes, a model for osteoarthritis. Mol Med Rep. 2017; 16: 1369-1375. [CrossRef]

[30] Parhiz H, Roohbakhsh A, Soltani F, Rezaee R, Iranshahi M. Antioxidant and anti-inflammatory properties of the citrus flavonoids hesperidin and hesperetin: An updated review of their molecular mechanisms and experimental models. Phytother Res. 2015; 29: 323-331. [CrossRef] 